\title{
Chamberlainium pentagonum (CONTI) comb. nov. and Spongites fruticulosus (Corallinales, Rhodophyta) in the Miocene carbonates of the western Mediterranean
}

\author{
Giovanni Colettr ${ }^{1 *}, 2$ \\ Juraj HRABOvSKÝ ${ }^{3}$ \\ Daniela BASSo ${ }^{2}$
}

\begin{abstract}
Molecular phylogenetic analyses discovered an unexpected biodiversity of coralline algae in modern oceans. This species richness is unlikely to be an exclusive characteristic of recent ecosystems. With the aim to investigate fossil coralline biodiversity, a large dataset of western Mediterranean Miocene specimens, previously identified as Spongites fruticulosus (and synonymized taxa), have been revised based on the current taxonomic framework. The analysis recognized two distinct groups. The first group includes the specimens fitting within the current description of $S$. fruticulosus. The second group consists of Chamberlainium pentagonum comb. nov., the first fossil representative of the genus. This species has been separated from $S$. fruticulosus on the basis of its smaller conceptacles and its thinner conceptacle roof. The very same characters have been highlighted by modern molecular phylogenetic analyses for separating Chamberlainium from Spongites. Chamberlainium pentagonum, similarly to the fossil specimens of Spongites fruticulosus, occurs in most of the investigated area and the two species coexist in several localities, indicating a similar and broad ecological tolerance for both taxa. These results suggest that Miocene coralline algal biodiversity is probably underestimated and prove the convenience of using large datasets for the study of fossil coralline algae.
\end{abstract}

\section{Key-words:}

- Mediterranean Sea;

- Neogoniolithoideae;

- Chamberlainoideae;

- Corallinales;

- calcareous algae;

- taxonomy;

- type collections

Citation: Coletti G., Hrabovský J. \& Basso D. (2020).- Chamberlainium pentagonum (ConTI) comb. nov. and Spongites fruticulosus (Corallinales, Rhodophyta) in the Miocene carbonates of the western Mediterranean.- Carnets Geol., Madrid, vol. 20, no. 11, p. 223-240.

Résumé : Chamberlainium pentagonum (CONTI) n.comb. et Spongites fruticulosus (Corallinales, Rhodophyta) dans les calcaires miocènes de Méditerranée occidentale.- Des analyses phylogénétiques moléculaires ont révélé une biodiversité inattendue au sein des algues rouges calcaires des océans modernes. Il est peu probable que cette richesse des espèces soit une caractéristique exclusive des écosystèmes modernes. Afin d'étudier la biodiversité des algues rouges calcaires fossiles, un large ensemble de données issues d'échantillons du Miocène de la Méditerranée occidentale, auparavant identifiés comme Spongites fruticulosus (et ses synonymes juniors), a été révisé en s'appuyant sur le cadre taxinomique moderne. Cette analyse a identifié deux groupes distincts. Le premier groupe comporte les spécimens correspondant à la description actuelle de $S$. fruticulosus. Le second groupe est constitué par Chamberlainium pentagonum n.comb., premier fossile représentatif du genre. Cette espèce a été séparée de Spongites fruticulosus sur la base de la plus petite taille de ses conceptables et de l'épaisseur moindre du toit de ces derniers. Les mêmes caractéristiques ont été mises en évidence par les analyses phylogénétiques moléculaires modernes permettant de séparer Chamberlainium de Spongites. Chamberlainium pentagonum, tout comme les spécimens fossiles de Spongites fruticulosus,

\footnotetext{
$1 *$ Corresponding author
}

giovanni.coletti@unimib.it

${ }^{2}$ University of Milano-Bicocca, Department of Earth and Environmental Sciences, Piazza della Scienza 4, 20126 Milano (Italy)

${ }^{3}$ Earth Science Institute of the Slovak Academy of Sciences, Dúbravská cesta 9, 84005 Bratislava (Slovakia)

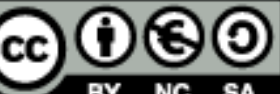

Published online in final form (pdf) on May 30, 2020

[Editor: Bruno GRANIER; language editor: Stephen EAGAR] 
est présent dans la majeure partie de la zone étudiée et ces deux espèces cohabitent dans plusieurs localités, indiquant une tolérance écologique large et similaire pour les deux taxons. Ces résultats suggèrent que la biodiversité des algues rouges calcaires miocènes est probablement sous-estimée ; ils montrent l'intérêt d'utiliser des ensembles de données conséquents pour étudier les algues rouges calcaires fossiles.

\section{Mots-clefs :}

- Mer Méditerranée ;

- Neogoniolithoideae ;

- Chamberlainoideae ;

- Corallinales ;

- calcareous algae ;

- taxinomie ;

- collections de types

\section{Introduction}

In the last decades, molecular phylogenetic analysis has driven a new revolution in biological taxonomy, including the classification of coralline algae. The genetic approach resulted in significant changes and revisions at higher taxonomic ranks (e.g., BAILEY \& ChAPMAN, 1998; HARVEY et al., 2003; Le Gall et al., 2010; BitTNer et al., 2011; Kato et al., 2011; NeLSON et al., 2015; RösLER et al., 2016; CARAGNANo et al., 2018), and the discovery of a previously unknown species diversity (e.g., PARDO et al., 2014; SISSINI et al., 2014; ADEY et al., 2015; BAHIA et al., 2015; BASSO et al., 2015; HeRnANDEZ-KANTUn et al., 2015, 2016; Nelson et al., 2015; MeRWE et al., 2015; Rösler et al., 2016; LiU et al., 2018; PeZzOLESI et al., 2019). These studies also revealed remarkable genetic separation between biogeographic provinces, suggesting that many apparently cosmopolitan species were actually heterogeneous mixtures of geographically separated entities, nearly indistinguishable from the morphological point of view (e.g., Sissini et al., 2014; MerWE et al., 2015; RösLer et al., 2016). In this context, the genus Spongites has changed its taxonomic position twice in the last years (KATO et al., 2011; RÖSLER et al., 2016). Molecular phylogenetic studies also proved that geographically separated populations, included in Spongites on a morphoanatomical basis, actually belong to different subfamilies (Merwe et al., 2015; Caragnano et al., 2018). Furthermore, it has been suggested that even the Mediterranean population of the type species, Spongites fruticulosus KüTZING (1841), could be formed from two separate entities (Rösler et al., 2016; CARAgnano et al., 2018). While these results suggest that the cosmopolitan $S$. fruticulosus is likely a complex of different species, for coralline algal paleontology, from the Oligocene onward and all around the world, $S$. fruticulosus seems to be almost the only species of its genus (AguirRe \& BRAGA, 2005). There are basically two reasons for this. First, paleontology can only rely on characteristics that can be preserved in the fossil record and many living species are based on characters that are either rarely preserved or not preservable at all. Second, until the type material of Lithophyllum albanense (LEMOINE, 1923) was rediscovered, reassessed, and synonymized with S. fruticulosus (BRAGA et al., 1993; AguirRe et al., 2012), paleontologists could rely only on the original description of the species, which was not sufficient for accurate taxonomic identifications. The original description of Lithophyllum albanense (LEMOINE, 1923: p. 281-282) did not have any illustrations of the microscopic anatomy of the specimen and presented only schematic drawings (LEMOINE, 1923: text-figs. 8-9). As a result, it is likely that over the years a number of similar species have been lumped together. The division of living coralline species is presently based on both DNA sequencing and morphology. While the former is obviously not possible with geological material, the latter gives results complying with DNA sequencing only when large and geographically extensive collections are analyzed (e.g., BAsso et al., 2015; ADEY et al., 2018). This approach is also quite effective for fossil material (Coletri et al., 2016), since it allows for a better comprehension of intraspecific variability. Therefore, in order to establish whether or not the fossil population of S. fruticulosus represents a morphologically uniform entity, we investigated a large collection of fossil coralline algae morphologically close to $S$. fruticulosus and discussed their placement within the current taxonomic framework.

\section{Material and methods}

The analysis included twenty-five thalli from different formations of the western Mediterranean area, ranging in age from the Burdigalian to the early Messinian (Fig. 1; Table S1). Some of the examined specimens have already been published as Spongites fruticulosus (and synonyms), while other specimens are unpublished (Fig. 1; Table 1). The holotype of Lithothamnion pentagonum CONTI (1943), an ill-defined species stored in the collection of the DISTAV of the Genova University (VANNUCCI et al., 2009), has been also reexamined. Although the examined thin sections of the specimens were prepared at different times (ranging from the 1940s to recently), the preparation technique is always the same. The specimen is embedded in epoxy resin and then cut with a rock saw. The resulting surface is polished with abrasive powder and then glued to a standard petrographic glass slide. The excess material is cut away with a rock saw and then the specimen is ground to a thickness of 30-40 $\mu \mathrm{m}$. For anatomical observations, the fossil specimens were observed in thin section under a light micro- 


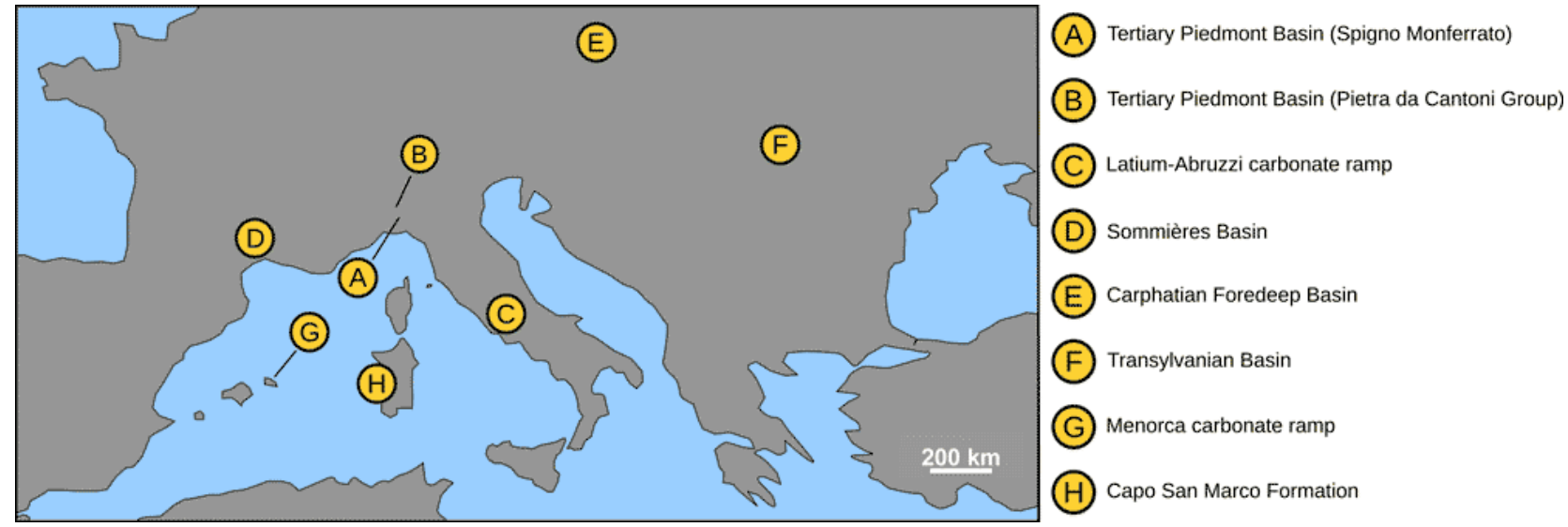

Figure 1: Geographic map of the studied localities.

scope. Growth-forms terminology follows WOELKERLING et al. (1993), while the terminology for the vegetative anatomy follows HRABOvSký et al. (2016), using hypothallus and perithallus as synonyms for ventral core of basal filaments and peripheral zone respectively. The vegetative anatomy was studied along longitudinal radial sections (QUARANTA et al., 2007; VANNUCCI et al., 2008). The cell length was measured as the distance between two primary pit connections including the cell wall; the diameter of the cells was measured perpendicular to cell length and includes the cell wall (BAsso et al., 1996). The reproductive anatomy was also investigated along radial sections. The conceptacles were measured along their axial sections (i.e., the section that cuts the chamber in its central part, resulting in the pore canal being visible; AfONSO-CARILLO et al., 1984; QUARANTA et al., 2007; VANNUCCI et al., 2008). The height of the conceptacle chamber was measured at the side of the columella (h2 sensu BAsso et al., 1996). Male gamentangial thalli have been recognized based on the presen- ce of uniporate conceptacles with a small diameter and a very low $(<0.25)$ height/diameter ratio (H/D). Female gametangial thalli have been recognized based on the presence of uniporate conceptacles yielding a low H/D and the presence of large inflated cavities presumably corresponding to carposporangial conceptacles produced by development of a carposporophyte within the fertilized female conceptacle (BASSo \& RoDONDI, 2006). Asexual sporangial thalli have been recognized based on the presence of conceptacles of uniform size within each of the examined specimens, and a regular H/D in respect of the known proportions observed in the living species. Sporangial and gametangial thalli have been considered as different reproductive stages of the same species only when they were exhibiting the same vegetative anatomy and they were located close to each other (e.g., same thin section or same stratigraphic layer) (BASSo et al., 1996; HRABOVSkÝ et al., 2016). The following abbreviations are used: $\mathrm{D}=$ diameter; $\mathrm{H}=$ height; $\mathrm{L}=$ length.

Table 1: Studied specimens, including localities, age and relevant literature; specimen numbers are in bold, the same identifying numbers are used throughout the paper.

\begin{tabular}{|c|c|c|}
\hline Locality & Age & Specimens \\
\hline $\begin{array}{l}\text { Tertiary Piedmont Basin } \\
\text { (Spigno Monferrato) }\end{array}$ & Burdigalian & $\begin{array}{l}\text { Specimens published as: [1] Lithothamnion pentagonum, CONTI, } \\
\text { 1943: Tav. VI.3a-e; Tav. VIII.4; [18, 19, 20] Spongites albanensis, } \\
\text { VANNUCCI et al., 1993; [24, 25] Lithophyllum platticarpum, VANNUCCI } \\
\text { et al., 1993: Tav. I.a }\end{array}$ \\
\hline $\begin{array}{l}\text { Tertiary Piedmont Basin } \\
\text { B (Pietra da Cantoni Group) }\end{array}$ & Burdigalian & Unpublished specimens $[16,17,23]$ \\
\hline $\begin{array}{l}\text { Latium-Abruzzi } \\
\text { carbonate ramp }\end{array}$ & Burdigalian & $\begin{array}{l}\text { Specimens [3, 4, 5] published as Spongites sp., BRANDANO et al., } \\
\text { 2007: text-fig. 5.b }\end{array}$ \\
\hline Sommières Basin & Burdigalian & $\begin{array}{l}\text { Specimens [21, 22] published as Spongites fruticulosus, COLETTI } \\
\text { al., 2018a: text-fig. 6.E; text-fig. S.3; table }\end{array}$ \\
\hline E Carpathian Foredeep Basin & Early Langhian & $\begin{array}{l}\text { Specimen [13] published as Spongites fruticulosus, HRABOVSKÝ et al., } \\
\text { 2016: text-fig. 17.A; specimens }[\mathbf{1 4}, \mathbf{1 5}] \text { published as Spongites Do- } \\
\text { LÁKOVÁ et al., 2014. }\end{array}$ \\
\hline Transylvanian Basin & Early Langhian & Unpublished specimens $[\mathbf{9}, \mathbf{1 0}, \mathbf{1 1}, \mathbf{1 2}]$ \\
\hline G Menorca carbonate ramp & Early Tortonian & $\begin{array}{l}\text { Specimens }[\mathbf{6}, \mathbf{7}, \mathbf{8}] \text { published as Spongites, BRANDANO et al., 2005: } \\
\text { text-fig. } 9\end{array}$ \\
\hline $\begin{array}{l}\text { H Capo San Marco Formation } \\
\text { (Sardinia) }\end{array}$ & Messinian & $\begin{array}{l}\text { Specimen [2] published as Lithophyllum albanense, FRAVEGA et al., } \\
1988\end{array}$ \\
\hline
\end{tabular}




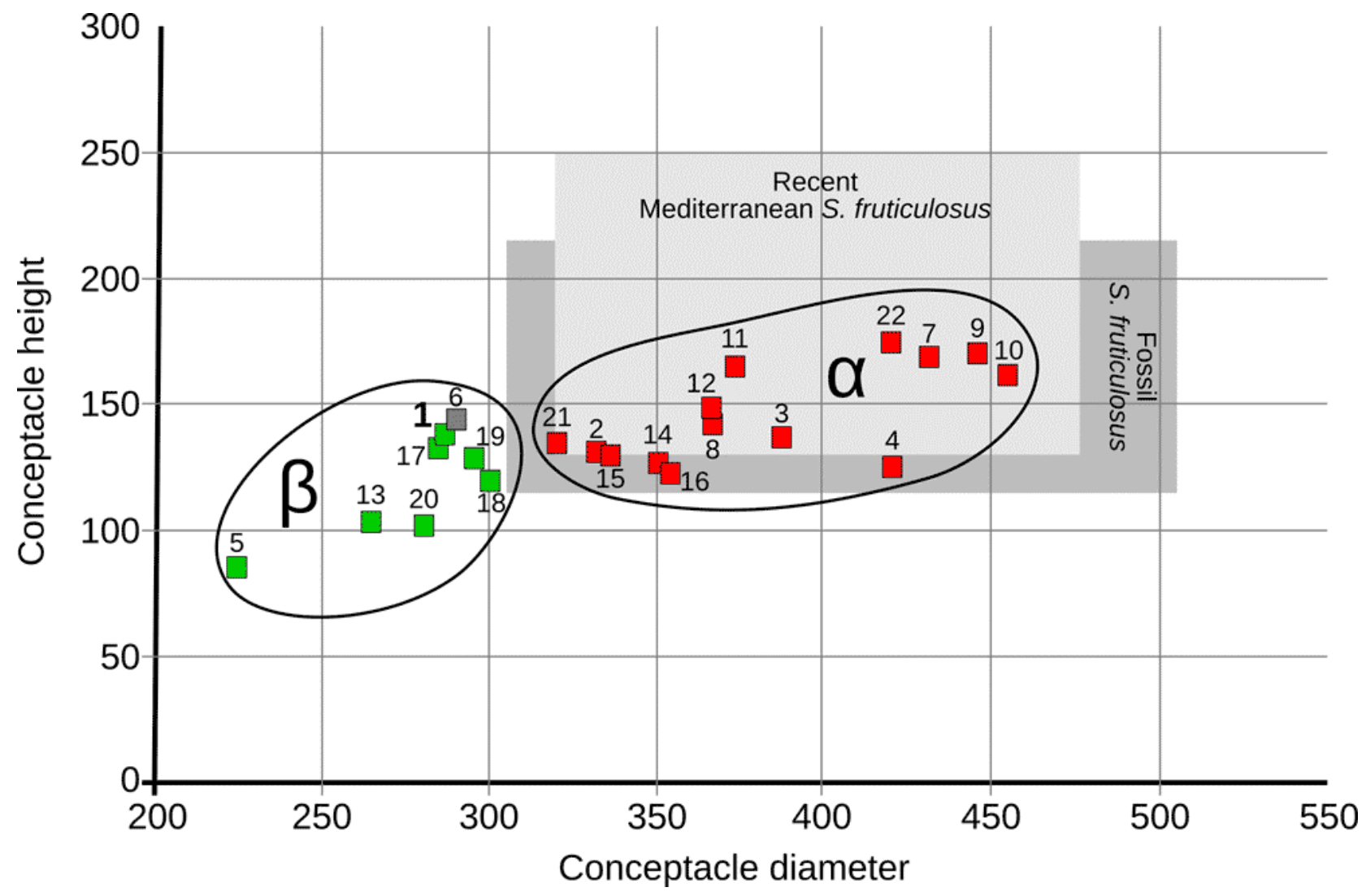

Figure 2: Scatter-plot including the values of conceptacle diameter $(\mu \mathrm{m})$ and conceptacle height $(\mu \mathrm{m})$ for all the examined sporangial thalli; green squares indicate dimerous specimens; red squares indicate monomerous specimens; specimen 6 is indicated by a gray square since the hypothallial portion of the thallus was not observed; the light grey field indicates the known variability of conceptacles size for the modern Mediterranean population of Spongites fruticulosus; the dark gray field indicates the known variability of LEMOINE's type material of Lithophyllum albanense, reassessed, and synonymized with S. fruticulosus by AGUIRRE et al. (2012).

\section{Paleoecological setting}

The Burdigalian specimens of the LatiumAbruzzi carbonate ramp (specimens 3, 4, 5), Tertiary Piedmont Basin (specimens 1, 16, 17, $18,19,20,23,24,25$ ) and Sommières Basin (specimens 21,22 ) are related to similar environmental conditions. During the Burdigalian these areas were characterized by a tropical to sub-tropical climate and nutrient-rich waters, leading to the formation of carbonate facies dominated by coralline algae, large benthic foraminifera, barnacles, bryozoans and mollusks (VANNUCCI et al., 1993; BRANDANO \& CORDA, 2002; BRANDANO et al., 2007, 2017; ReYNAUd \& JAMES, 2012; Coletti et al., 2015, 2017, 2018a, 2018b), with hermatypic corals occurring only locally (BRANDANO et al., 2007). The paleoenvironment of the early Langhian specimens of the Carphatian Foredeep Basin (specimens 13,14, 15) and of the Transylvanian Basin (specimens 9, 10, 11, 12), was also characterized by warm to subtropical conditions (SAINT-MARTIN et al., 2007; DolÁkovÁ et al., 2008, 2014; ChelARU et al., 2019). The related skeletal assemblage was dominated by coralline algae, bryozoans and molluscs, associated with serpulids, benthic foraminifers, echinoids and hermatypic corals (the latter in the area of Lopadea Veche) (BUCUR \& FILIPESCU, 1994; FiliPESCU \& GîRBACEA, 1997; SAINT-MARTIN et al., 2007; DolÁKovÁ et al., 2008, 2014). The early Tortonian specimens (specimens 6, 7, 8) from Menorca (Lower Bar Unit, Pomar et al., 2002; BRANDANo et al., 2005), are related to a high-energy, tropical, middleramp environment, where carbonate production was dominated by coralline algae, mollusks, echinoids, bryozoans and large benthic foraminifera (BRANDANO et al., 2005). The early Messinian specimen of the Capo San Marco Formation (2) is associated with a skeletal assemblage dominated by mollusks, coralline algae, bryozoans and brachiopods (CHERCHI et al., 1978; FRAVEGA et al., 1988). This limestone testifies the last episode of marine deposition in the area before the Messinian Salinity Crisis and is related to a coastal, shallow-water environment (CHERCHI et al., 1978; FRAVEGA et al., 1988). Overall, all the examined specimens are related to warm-temperate to tropical shallow-water conditions.

Figure 3: Vegetative anatomy of group a (S. fruticulosus). A) Encrusting growth form; specimen 9, locality F. B) Fruticose growth form; specimen 3, locality C. C) Monomerous organization with non-coaxial hypothallus; black arrowheads $=$ hypothallial filaments bending upward and forming perithallus; specimen 9, locality F. D) Non-coaxial hy- 

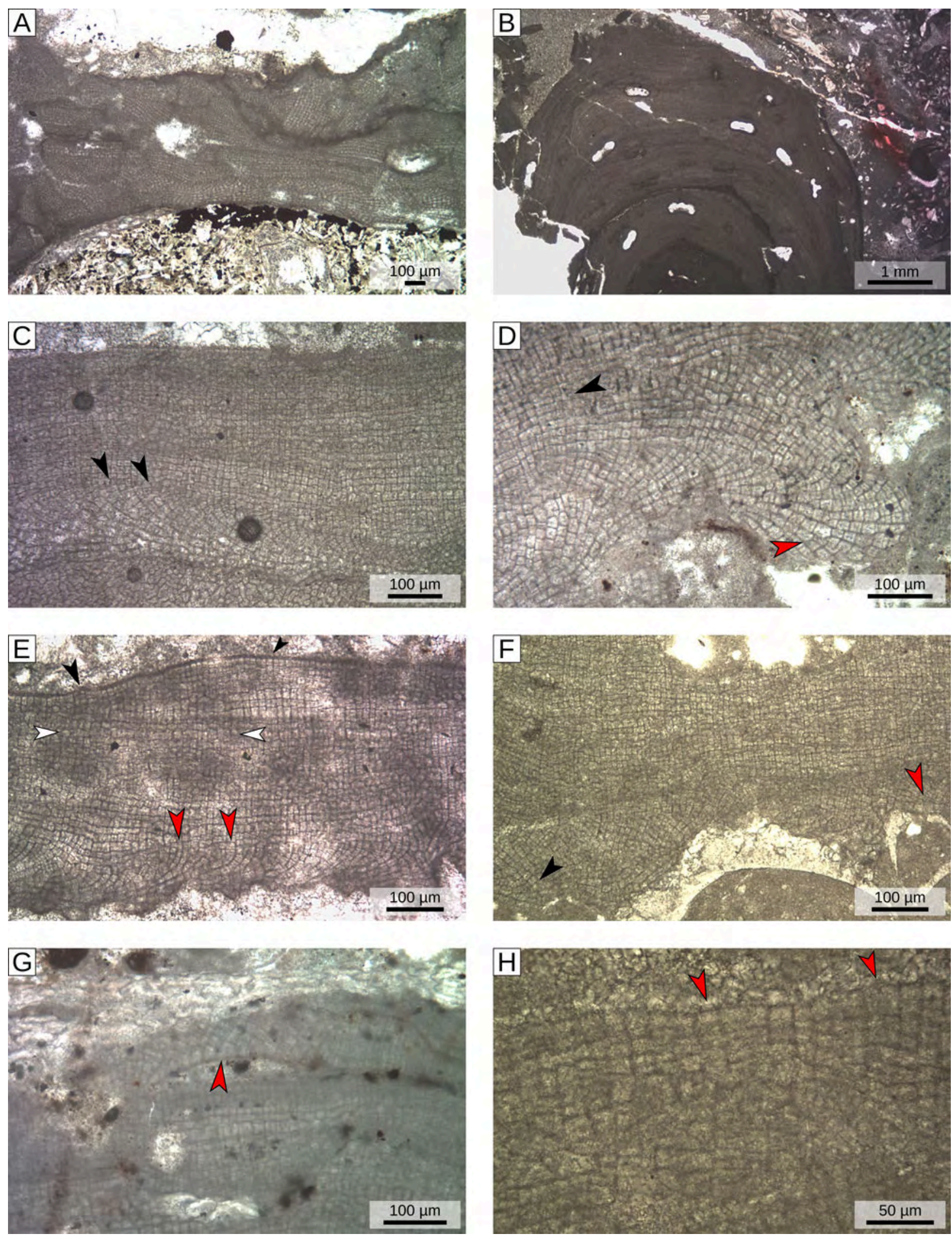

pothallus; red arrowhead= dichotomous branching of hypothallial filaments; black arrowheads= regularly organized perithallus; specimen 11, locality F. E) Monomerous organization with a non-coaxial hypothallus; red arrowheads= hypothallial filaments bending upward and forming perithallus; white arrowheads= poorly organized perithallus; black arrowheads= dome-shaped epithallial cells; specimen 7, locality G. F) Monomerous organization (black arrowhead) locally turning into dimerous organization (red arrowhead); specimen 16, locality B. G) Dimerous organization developing over a scar in the perithallus (red arrowhead); specimen 12, locality F. H) Dome-shaped epithallial cells (red arrowheads); specimen 16, locality B. 

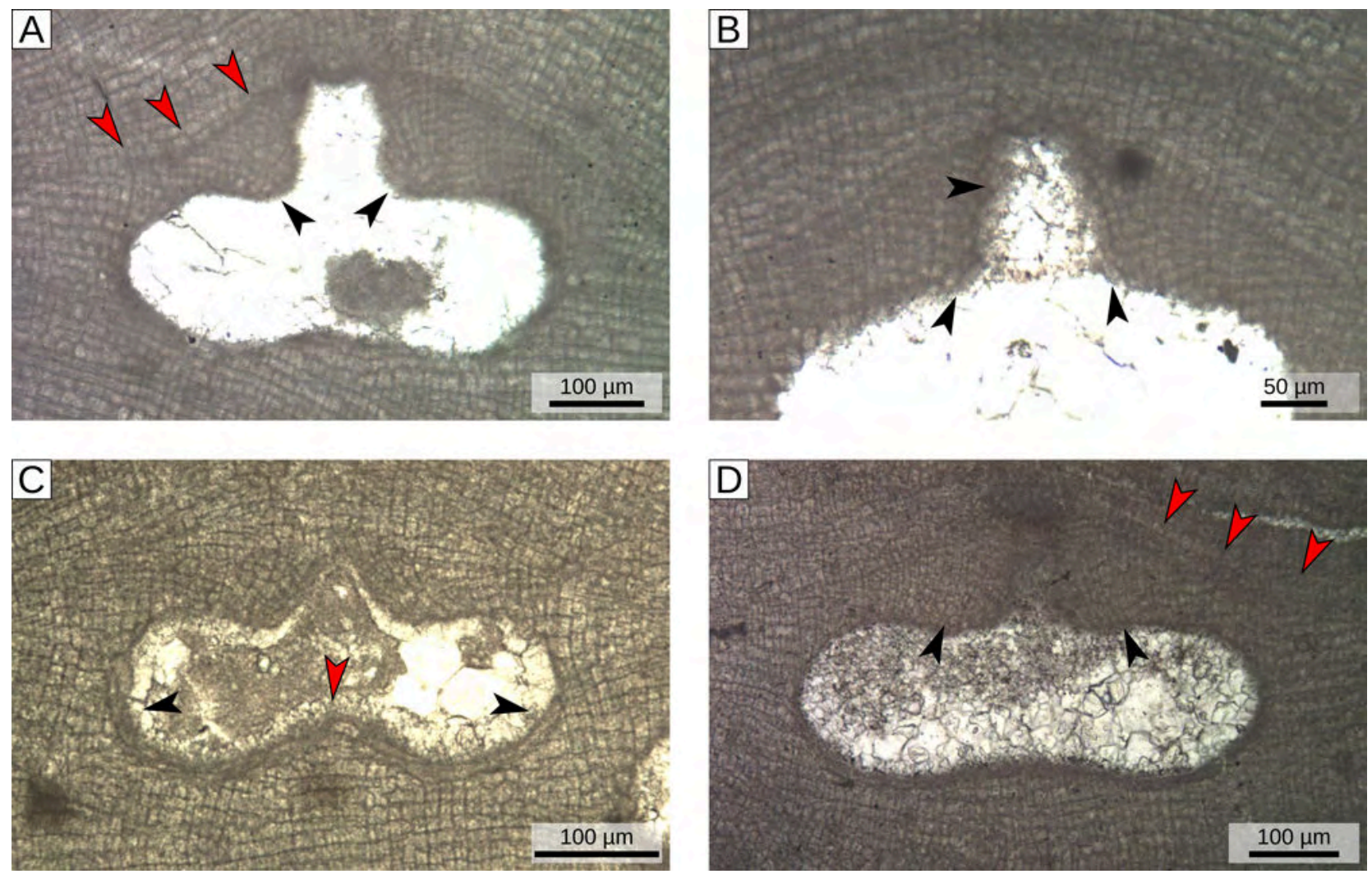

Figure 4: Asexual reproductive anatomy of group a (S. fruticulosus). A) Flask-shaped uniporate sporangial conceptacle lined by cells filaments that protrude into the pore canal (black arrowheads); red arrowheads= conceptacle roof originally protruding above the surrounding thallus surface; specimen 9, locality F. B) Magnified view of sporangial conceptacle roof with cell filaments protruding into pore canal (black arrowheads); specimen 9, locality F. C) Sporangial conceptacle lined by cell filaments (black arrowheads); red arrowhead= central columella; specimen 16, locality B. D) Magnified view of the roof that was clearly raised (red arrowheads) compared to the surrounding thallus surface; black arrowheads = filaments of small cells (with $>8$ cells) composing the roof of the conceptacle; specimen 10 locality $\mathrm{F}$.

\section{Results}

The analyzed specimens can be broadly divided into two groups (Fig. 2): a) specimens that are morphologically and anatomically strictly corresponding to the modern concept of Spongites fruticulosus (BASSO \& RoDONDI, 2006); $\beta$ ) specimens that are not corresponding to the modern concept of $S$. fruticulosus. All the morphometric data of the investigated specimens are provided in the supplementary material (Table S1).

\section{Group a: Spongites fruticulosus}

This group includes 14 sporangial thalli (specimens: $2,3,4,7-12,14-16,21,22$ ) from every studied locality, except Spigno Monferrato (locality A) (Figs. 1 - 2; Table 1 ). The thalli present encrusting (Fig. 3.A), warty or fruticose growth forms (Fig. 3.B) and are characterized by a mainly monomerous organization (Fig. 3.C-E). The hypothallus consists of several layers of rectangular cells (mean size: D $12.3 \mu \mathrm{m} ; \mathrm{L} 19.1 \mu \mathrm{m}$ ) and lacks a coaxial organization (Fig. 3.D; Table S1). Each filament of hypothallial cells bends toward the thallus surface to form the perithallus (Fig. 3.C, 3.E). Locally the thallus may show a dime- rous organization characterized by a basal layer of irregularly squared cells (Fig. 3.F-G) as observed in recent specimens of the species (BASSO \& RoDONDI, 2006). The perithallus is composed of rectangular cells with a mean $D$ of $10.8 \mu \mathrm{m}$ and $a$ mean $\mathrm{L}$ of $12.8 \mu \mathrm{m}$ (Table $\mathrm{S} 1$ ). The perithallus is locally grid-like (Fig. 3.D), while elsewhere, owing to the large number of wide cell fusions, the grid become less regular and the separation between cells of contiguous filaments appears less evident than the separation between cells of the same filament (Fig. 3.E). Epithallial cells are dome-shaped and much smaller than the average perithallial cells (Fig. 3.E, 3.H). Trichocytes were not observed.

Sporangial plants present flask-shaped uniporate conceptacles (Fig. 4.A), with conceptacle roof formed from cell filaments lining the outer border of the chamber and protruding into the pore canal (type 1 sensu JoHANSEN, 1981) (Fig. 4.B-C). The chamber has a mean size of $380 \mu \mathrm{m}$ (D) $\times 145 \mu \mathrm{m}(\mathrm{H})$, while on average the pore-canal is $110 \mu \mathrm{m}$ long and has a basal diameter of $100 \mu \mathrm{m}$ (Fig. 4.A-B; Table S1). The central part of the floor of the conceptacle chamber is gene- 

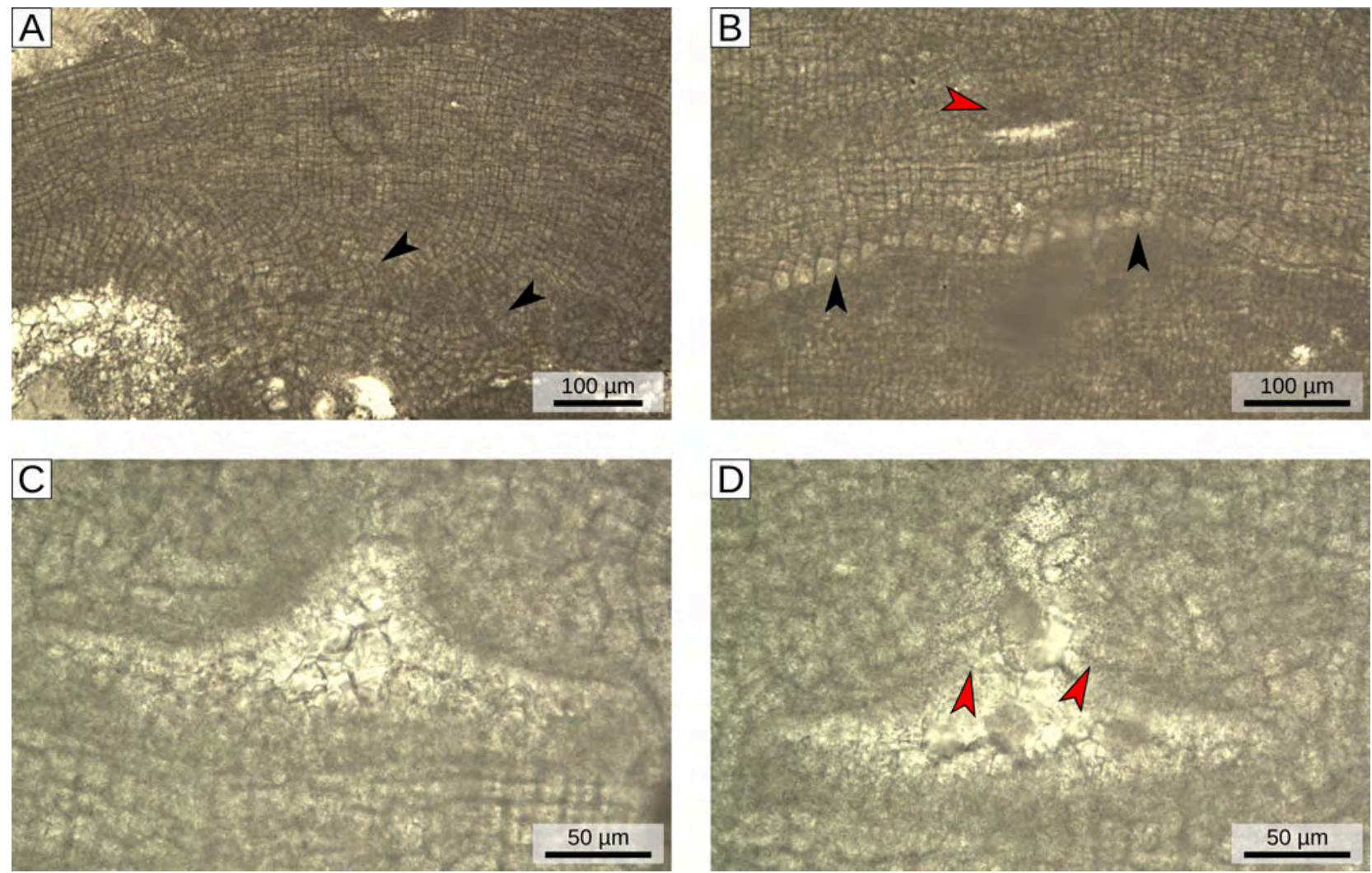

Figure 5: Vegetative and gametangial reproductive anatomy of group a (S. fruticulosus) (specimen 23, locality B). A) Vertical section of vegetative thallus with a monomerous organization; black arrowheads= non-coaxial hypothallus. B) Portion of the thallus with dimerous organization; black arrowheads= basal layer of cells; red arrowhead= conceptacle. C) Magnified view of a gametangial conceptacle. D) Magnified view of a presumed gametangial conceptacle with conceptacle roof lined by cells filaments that protrude into the pore canal (red arrowheads).

rally raised forming a calcified columella (Fig. 4.C). The chamber has an average roof thickness of $90 \mu \mathrm{m}$ and the roof is composed of cells (generally more than 8 ) slightly smaller and shorter than normal perithallial cells (Fig. 4.B, 4.D). The conceptacles slightly protrude above the surrounding thallus surface (Fig. 4.A, 4.D). Specimen 23 (Tertiary Piedmont Basin, locality $B$ ) has been considered as a gametangial plant, since it presents small and narrow conceptacles (mean size: D $145 \mu \mathrm{m} \times \mathrm{H} 25 \mu \mathrm{m} ; \mathrm{H} / \mathrm{D}$ of 0.17 ; Table S1), and shares the same vegetative anatomy of the sporangial plant with which is associated (specimen 16, Tertiary Piedmont Basin, locality B) (Fig. 5; Table S1).

\section{Group B: Chamberlainium pentagonum}

This group includes 8 sporangial thalli (specimens: 1, 5, 6, 13, 17-20, from the localities A, C, $\mathrm{E}, \mathrm{G})$ (Figs. 1 - 2; Table 1), including the holotype of Lithothamnion pentagonum CONTI (specimen 1, Tertiary Piedmont Basin, locality A). Differently from group $a$, these algae mainly present an encrusting growth morphology (Fig. 6.A-B) characterized by a dimerous organization (Fig. 6.B-C). The basal layer of cells consists of irregularly squared to palisade-like large cells (mean size: D $19.9 \mu \mathrm{m}$; L $16.6 \mu \mathrm{m}$ ) (Fig. 6.C; Table S1).
The other vegetative characters do not differ from the first group (Table S1).

Sporangial plants have flask-shaped conceptacles with conceptacle roof formed from cell filaments lining the outer border of the chamber and protruding into the pore canal (type 1 sensu JOHANSEN, 1981) (Fig. 6.D-F). The conceptacles are slightly protruding above the surrounding thallus surface (Fig. 6.E-F). The chamber is smaller than in group $a$, with a mean size of $280 \mu \mathrm{m}$ (D) $x 120 \mu \mathrm{m}(\mathrm{H})$ (Table S1). The central part of the floor of the conceptacle chamber is generally slightly raised forming a faint calcified columella (Fig. 6.E). Pore canals, on average, are $75 \mu \mathrm{m}$ in length and $80 \mu \mathrm{m}$ wide at the base (Fig. 6.E-F; Table S1). On average the roof is $55 \mu \mathrm{m}$ thick and is composed of cells slightly smaller than the average perithallial cells (generally less than 8 cells) (Fig. 6.F). Specimens 24 and 25 (Tertiary Piedmont Basin, locality A) show very small and narrow conceptacles (mean size: D $120 \mu \mathrm{m} ; \mathrm{H} 25$ $\mu \mathrm{m}$; average $\mathrm{H} / \mathrm{D}=0.2$ ) (Fig. 6.H; Table S1). On the basis of their conceptacles shape and biometry, their vegetative anatomy, and their close association with specimens 18,19 and 20 (Tertiary Piedmont Basin, locality A), they were considered male gametangial plants (Fig. 6.G-H). 

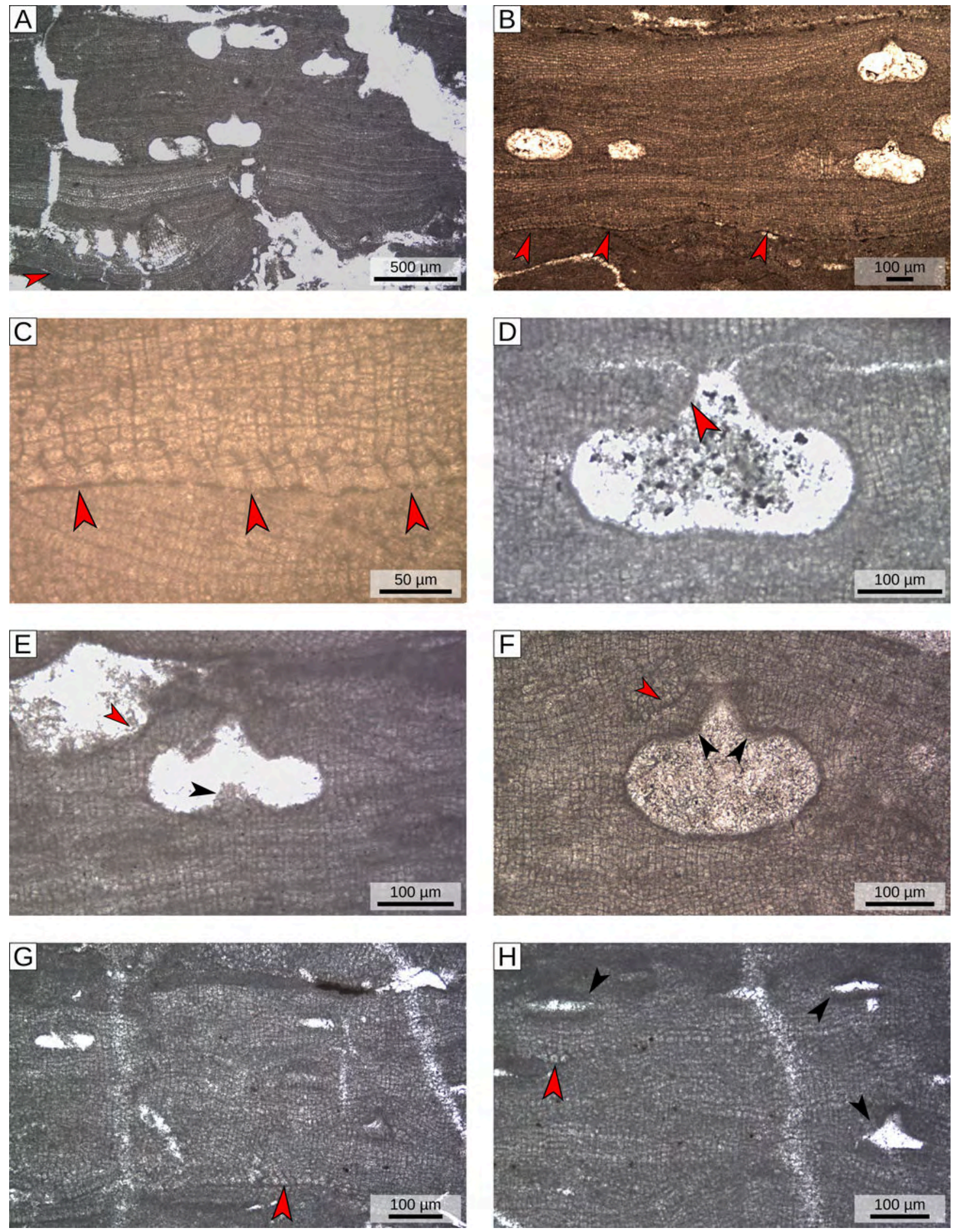

Figure 6: Vegetative and reproductive anatomy of group $\beta$ (C. pentagonum). A) Encrusting growth-form characterized by dimerous organization (red arrowhead); specimen 18, locality A. B) Encrusting growth-form characterized by dimerous organization (red arrowheads); specimen 17, locality B. C) Magnified view of the basal layer of cells (red arrowheads), showing the dimerous hypothallus; specimen 17, locality B. D) Flask-shaped uniporate asexual conceptacles with conceptacle roof formed from cell filaments protruding into the pore canal (red arrowhead); specimen 18, locality A. E) Uniporate asexual conceptacle revealing a calcified columella (black arrowhead); red arrowhead= 


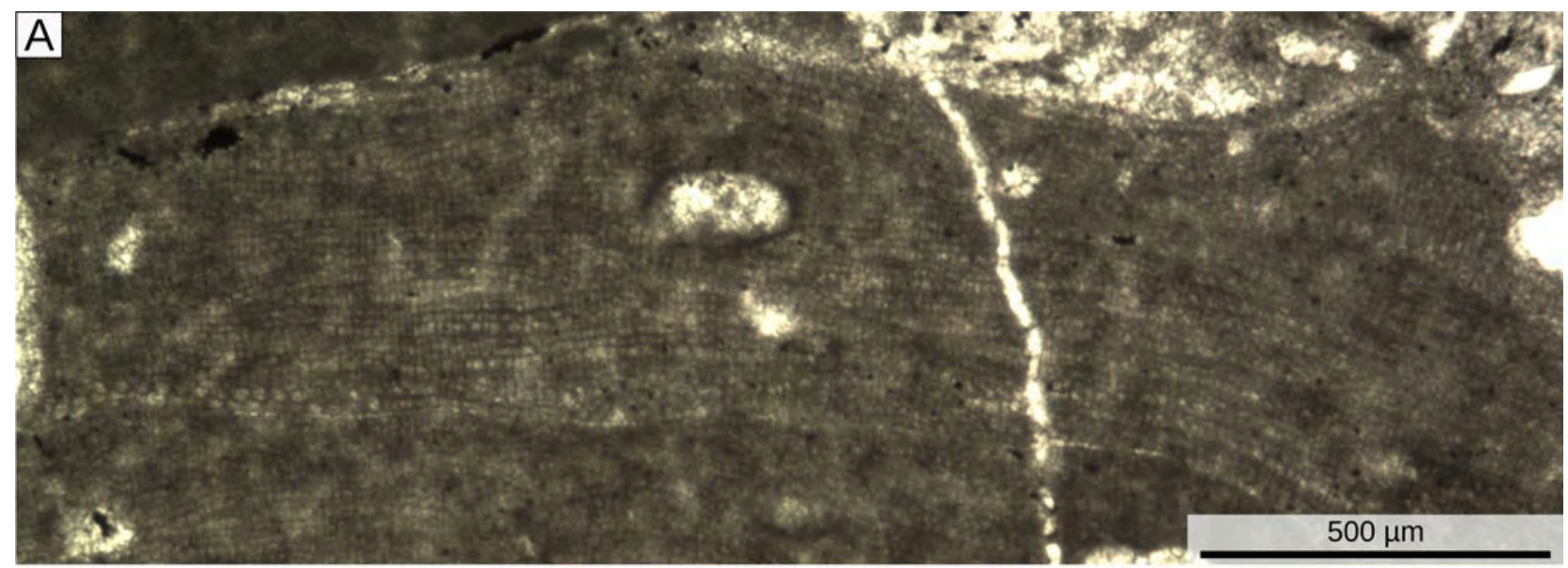

B
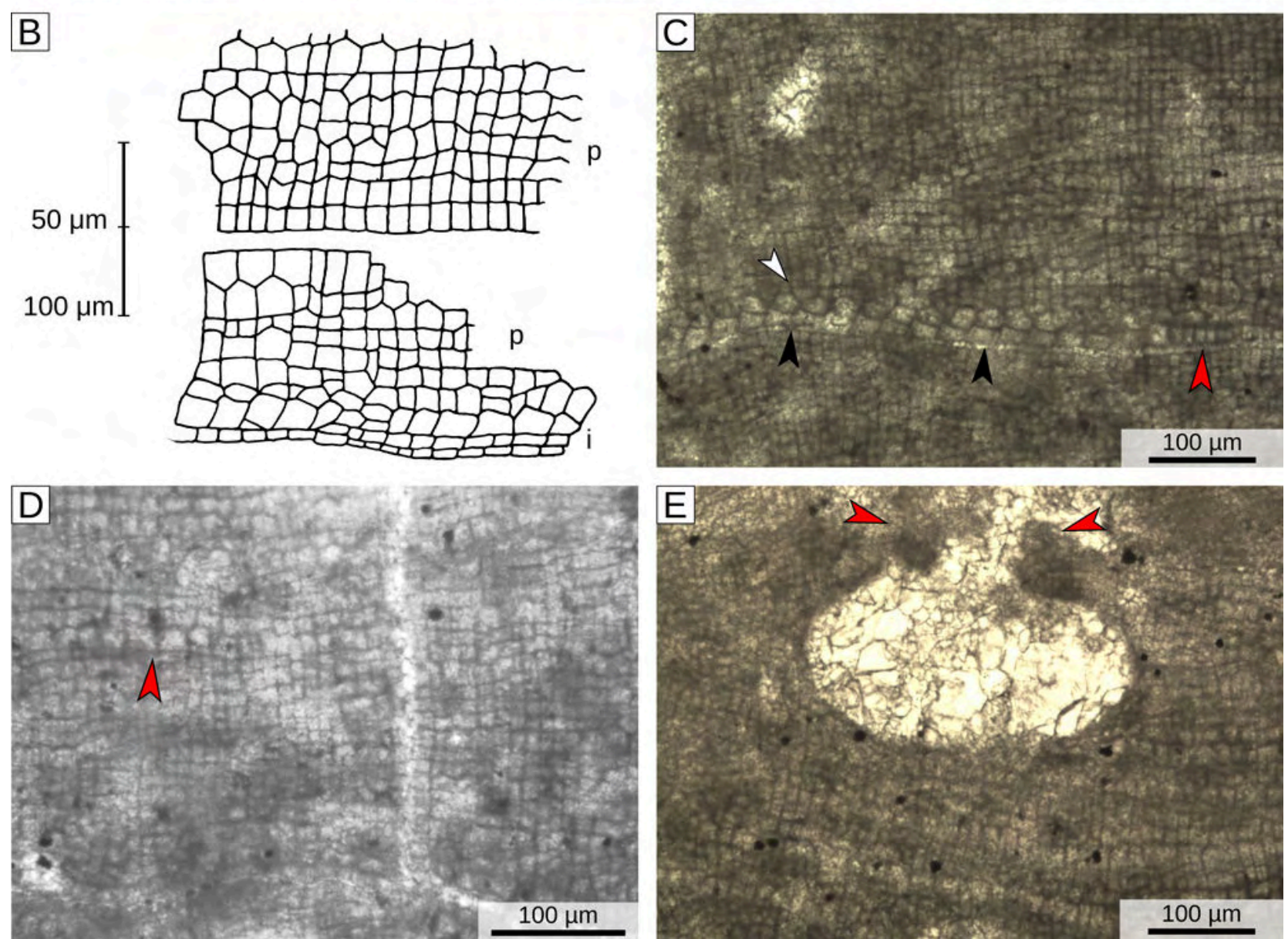

Figure 7: Holotype of Chamberlainium pentagonum (CONTI, 1943), early Burdigalian, specimen 1, locality A. A) Vertical section of the thallus. B) Reproduction of CONTI original sketches of vegetative anatomy, taken from CoNTI (1943); $p=$ perithallus; $i=$ hypothallus. C) Dimerous construction with the basal layer composed of irregularly squared (black arrowheads) to palisade-like cells (red arrowhead); white arrowhead= dichotomous division of the first cells that arise from the basal layer, producing two rows of erect filaments. D) Erect filaments with large and irregular cells (red arrowhead) created by the complete resorption of the wall separating the cells. E) Small ellipsoidal conceptacle with a thin roof (red arrowheads).

bending of the thallus surface indicating that the conceptacle was originally raised compared to the surrounding thallus surface; specimen 5, locality C. F) Uniporate asexual conceptacle with a thin roof composed of less than 8 cells (red arrowhead); black arrowheads= cell filaments protruding into the pore canal; specimen 6, locality G. G) Vertical section of vegetative thallus showing male conceptacles; red arrowhead= basal layer of cells revealing a dimerous hypothallus; specimen 24, locality A. H) Uniporate male conceptacles (black arrowheads), red arrowhead= secondary growth of a basal layer of cells, revealing a dimerous secondary hypothallus; specimen 24 locality A. 
Overall, the specimens of this group fit with the description of the recently established genus Chamberlainium (Merwe et al., 2015; CaRAGnano et al., 2018). Since the holotype of Lithothamnion pentagonum (CONTI, 1943), which has been reexamined and included in this analysis (specimen 1; Tertiary Piedmont Basin, locality B) (Figs. 1 2,8 ), belong to this group, we propose for this species a new combination under the genus Chamberlainium and an emended description that includes all the examined specimens of group $\beta$.

Class Florideophyceae CRONQUIST, 1960

\section{Subclass Corallinophycideae Le GALL \& SAUNDERS, 2007}

\section{Order Corallinales SiLVA \& JOHANSEN, 1986}

\section{Family Corallinaceae (LAMOUROUX, 1812) HARVEY et al., 2003}

\section{Subfamily Chamberlainoideae CARAgnano et al., 2018}

\section{Genus Chamberlainium Caragnano et al., 2018}

Type-species: Chamberlainium (Foslie, 1900) CARAgnano et al., 2018

tumidum

\section{Chamberlainium pentagonum (CONTI, 1943) comb. nov.}

Basionym: Lithothamnium pentagonum CoNTI, 1943, Tav. VI 3a-e; Tav. VIII 4.

Holotype description: The holotype of "Lithothamnium pentagonum" is the thin section labeled as 22 of the ConTI Collection (1943-1946; Miocene, Ponzone - Alessandria, NW Italy; $2 \mathrm{~km}$ westward from Spigno Monferrato) stored at the DISTAV of the Genova University. It consists of a rhodolith composed of various and different coralline algal crusts, including the holotype of $L$. pentagonum (Fig. 7.A). In thin section 22 it is possible to recognize the portion of thallus illustrated in Contr's protologue (Fig. 7.B; VANNuCCI et al., 2009). It should be noted that the cavity sketched in Contr's drawing (Tav. VI [II], fig. 3.e in CONTI, 1943) is probably not a conceptacle. The holotype is an encrusting specimen $500 \mu \mathrm{m}$ thick, which overgrows other coralline algae (Fig. 7.A). The thallus has a dimerous construction with the basal layer composed of irregularly squared to palisade-shaped large cells, 20 to $29 \mu \mathrm{m}$ in diameter and 10.5 to $21 \mu \mathrm{m}$ in length (mean size: D $25.5 \mu \mathrm{m} ; \mathrm{L} 15.7 \mu \mathrm{m}$ ) (Fig. 7.C; Table S1). The first cells arising from the basal layer are often roughly pentagonal and divide dichotomously producing two rows of erect filaments that combined are more or less as wide as the cell from which they are derived (Fig. 7.C). The perithallus is composed of irregularly rectangular cells 8 to $18 \mu \mathrm{m}$ long and with a diameter of 8 to $14 \mu \mathrm{m}$ (mean size: D $10.7 \mu \mathrm{m}$; L $13.4 \mu \mathrm{m}$ ) (Fig. 7.D; Table S1). Fusions between cells of contiguous filaments are abundant and frequently occupy most of the adjoining cell wall. The large and irregularly pentagonal cells described by CONTI are produced by cell fusions (Fig. 7.D). Epithallial cells are small and dome-shaped. Trichocytes were not observed. The conceptacles are poorly preserved; they are uniporate and elliptical in shape, with internal chambers 230 to $300 \mu \mathrm{m}$ in diameter and 125 to $160 \mu \mathrm{m}$ in height (mean size: D $285 \mu \mathrm{m} ; \mathrm{H} 140 \mu \mathrm{m})$ (Fig. 7.E; Table S1). The floor of the conceptacle chamber is raised centrally. The roof seems to be very thin and composed of cells smaller than those of the perithallus (Fig. 7.E).

Emended diagnosis: Encrusting growth form; dimerous construction; hypothallus composed of irregularly squared (in longitudinal radial section) to palisade-like cells in radial view (tangential section along the filaments); perithallus with common cell fusions; epithallial cells domeshaped; sporangial conceptacles uniporate with the conceptacle chamber lined by cell filaments protruding into the pore canal; conceptacle chamber with an average diameter around 275 $\mu \mathrm{m}$ and always less than $300 \mu \mathrm{m}$; average roof thickness of less than $70 \mu \mathrm{m}$.

\section{Discussion and conclusions}

Based on the description of the modern Mediterranean population of Spongites fruticulosus provided by BASSO and RODONDI (2006), the specimens of group a are conspecific with the Mediterranean S. fruticulosus. Their morphology also complies with the description of LEMOINE's type material of Spongites albanensis (AgUIRRE et al., 2012) (Fig. 2). Male gametangial plants similar to those of the Tertiary Piedmont Basin (specimen 23 , locality B) are already known in the fossil record and are often identified as Lithophyllum platticarpum MASLOV (1962) which has been recognized as a gametangial plant by BRAGA et al. (2005) and synonymized with S. fruticulosus by ChelARU and BUCUR (2016). These results show that $S$. fruticulosus is indeed common in the Miocene carbonates of the western Mediterranean. Recent studies highlighted that the modern Mediterranean population of $S$. fruticulosus comprises at least two species, genetically different but morpho-anatomically very similar (RösLER et al., 2016; CARAgnano et al., 2018). Among the specimens examined in this work and assigned to $S$. fruticulous, it is possible to recognize two different sub-groups, one characterized by smaller conceptacles (specimens 2, 3, 8, 11, 12, 14, 15, $16,21)$ and one with larger conceptacles (specimens 4, 7, 9, 10, 22) (Figs. 2, 8). Although these two groups could actually represent two different species, the data available on both the modern population and the fossil record are not sufficient for a definitive conclusion to be drawn. 


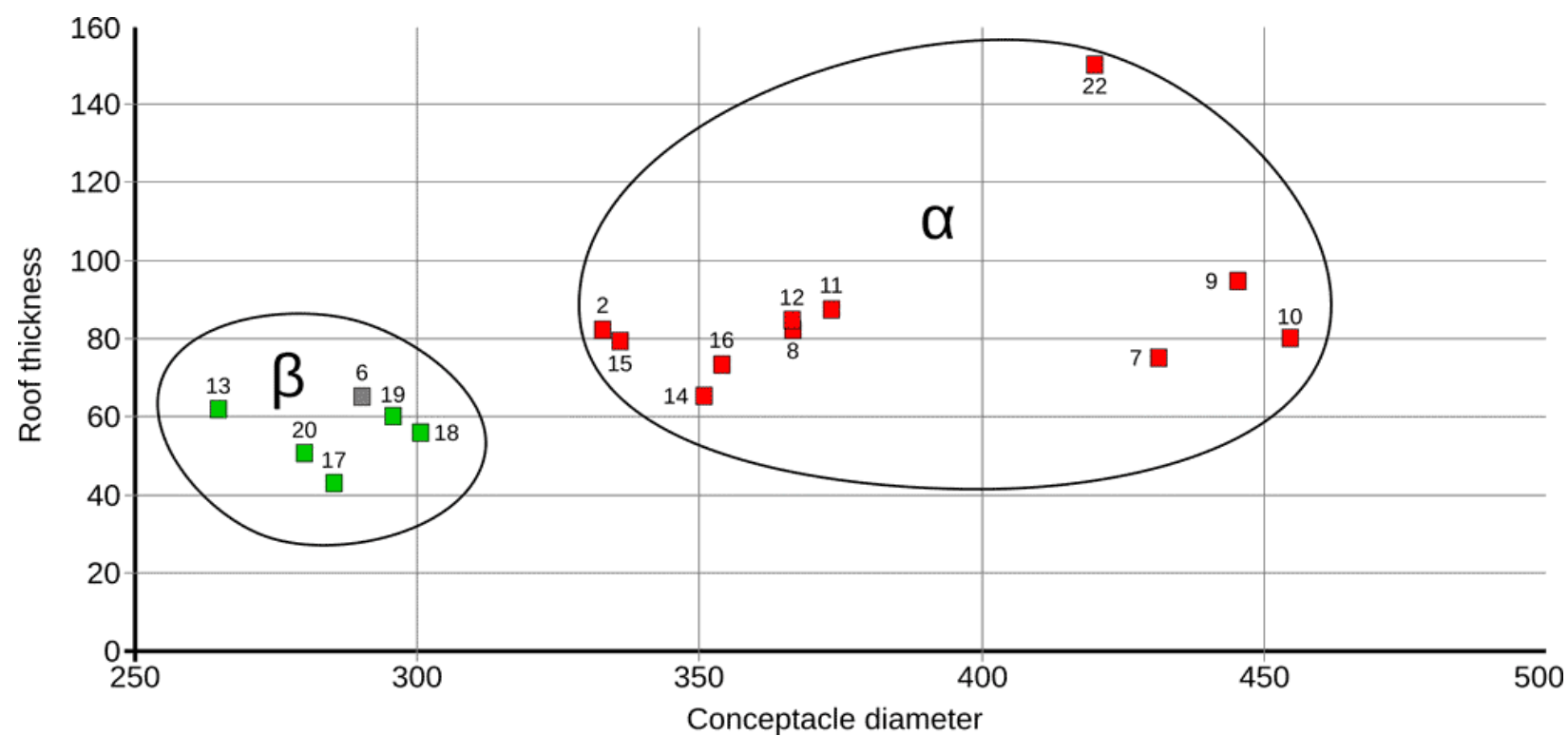

Figure 8: Scatter-plot including the values of conceptacle diameter $(\mu \mathrm{m})$ and roof thickness $(\mu \mathrm{m})$ for specimens of both groups (only the specimens with both measurements were included). Green squares indicate dimerous specimens; red squares indicate monomerous specimens; specimen 6 is indicated by a gray square since the hypothallial portion of the thallus was not observed.

The specimens of group $\beta$, are characterized by small conceptacles, thin roof and a dimerous construction and have been included in the genus Chamberlainium (Merwe et al., 2015; CARAGNANO et al., 2018). Although this genus belongs to the newly established Chamberlainoideae sub-family, it is very similar to Spongites, which belong to the Neogoniolithoideae sub-family (CARAGNANO et al., 2018). Differently from Spongites, Chamberlainium is characterized by sporangial conceptacles with a diameter of less than $300 \mu \mathrm{m}$, a thin roof (less than 8 cells thick), and, in species with a dimerous organization, by a basal layer of palisade-like cells (in tangential sections) (CARAGNANo et al., 2018). By using conceptacle diameter and roof thickness it is possible to clearly isolate $S$. fruticulosus (group a) from $C$. pentagonum (group $\beta$ ) (Fig. 8), indicating that the morphological characters recognized by CARAGNANO et al. (2018) in modern algae work very well also with fossil ones. Presently, Chamberlainium is reported to occur along the coasts of the Indo-Pacific Ocean (South Africa, Taiwan and California, while it is absent from the Mediterranean (CARAGNANO et al., 2018). However, the presence of an Indo-Pacific species in the Mediterranean during the Miocene is not surprising since the two oceans were strongly connected during the early Miocene and limited connections existed also during the middle Miocene (CORNACCHIA et al., 2018, and references therein).

During the Miocene, both $S$. fruticulosus and C. pentagonum, where widespread in the western Mediterranean region, occurring both in the northern and southern part of the investigated area (Fig. 1; Table 1). Furthermore, in several localities the two species occured together, indicating for both taxa a broad ecological tolerance. Based on the associated skeletal assemblage, both species apparently thrived in warm-temperate to tropical conditions, but further researches are necessary to fully resolve their ecological preferences during the Miocene. At now the genus Chamberlainium seems to be confined to geographical regions characterized by strong seasonal variability of sea surface temperatures, while Spongites occurs in both warm-temperate (Mediterranean Sea) and tropical conditions (Maldives, Indian Ocean) (CARAGNANO et al., 2018). Therefore, similarly to their fossil counterparts, the living Chamberlainium and Spongites have a broad ecological tolerance and a preference toward warm water.

In accordance with the advancements in the study of living algae (HERNANDEZ-KANTUn et al., 2015; De Jode et al., 2019; Pezzolesi et al., 2019; RINDi et al., 2019), the results of this study indicate that Miocene coralline biodiversity in the western Mediterranean area was larger than expected, and that the best way to investigate this biodiversity is by using large data-sets of specimens and comparison with properly described type materials.

\section{Acknowledgments}

The authors would like to thank Annalisa CARAGNANO and Ramona CHELARU for their constructive revisions of the manuscript. Special thank also goes to the Editorial Board of Carnets Geol. for their courtesy and helpfulness. The authors are very grateful to Grazia VANNUCCI for her advice and useful suggestions and to Michele PIAZZA, Cristina BONCI and Sirio CONSANI, of the DISTAV of Genova University, for their help and support. The authors would also like to thank the Masaryk University for supporting $\mathrm{JH}$ 's investigations of the specimens analyzed in this work. 


\section{Bibliographic references}

Adey W.H., Hernandez-Kantun J.J., Gabrielson P.W., NASH M.C. \& HAYEK L.A.C. (2018).- Phymatolithon (Melobesioideae, Hapalidiales) in the boreal-subarctic transition zone of the North Atlantic. A correlation of plastid DNA markers with morpho-anatomy, ecology, and biogeography.- Smithsonian Contributions to the Marine Sciences, Washington, vol. 41, p. 1-90.

Adey W.H., Hernandez-Kantun J.J., Johnson G. \& GABRIELSON P.W. (2015).- DNA sequencing, anatomy and calcification patterns support a monophyletic, subartic, carbonate reef-forming Clathromophum (Hapalidiaceae, Corallinales, Rhodophyta).- Journal of Phycology, Moss Landing, vol. 51, no. 1, p. 189-203.

Aguirre J. \& Braga J.C. (2005).- The citation of nongeniculate fossil coralline red algal species in the twentieth century literature: An analysis with implications.- Revista Española de Micropaleontologia, Madrid, vol. 37, p. 57-62.

Aguirre J., Braga J.C., Reviers B. de \& WoelkerLING W.J. (2012).- Reassessment of LEMOINE'S newly discovered types of fossil corallines (Corallinales, Rhodophyta) preserved at the $\mathrm{Mu}$ séum National d'Histoire Naturelle, Paris.Cryptogamie, Algologie, Paris, vol. 33, p. 289326.

Afonso-Carillo J., Gil-Rodriguez M.C. \& WildPret T.W. (1984).- Estudios en las algas Corallinaceae (Rhodophyta) de las Islas Canarias. Aspectos metodologicos.- Vieraea, Tenerife, vol. 13, p. 113-125.

Bailey J.C. \& Chapman R.L. (1998).- A phylogenetic study of the Corallinales (Rhodophyta) based on nuclear small-subunit rRNA gene sequences.- Journal of Phycology, Moss Landing, vol. 34, p. 692-705.

Basso D., Caragnano A., Le Gall L. \& Rodondi G. (2015).- The genus Lithophyllum in the northwestern Indian Ocean, with description of $L$. yemenense sp. nov., $L$. socotraense sp. nov., L. subplicatum comb. et stat. nov., and the resumed L. affine, L. kaiseri, and L. subreduncum (Rhodophyta, Corallinales).- Phytotaxa, Auckland, vol. 208, p. 183-200.

Basso D., Fravega P. \& Vannucci G. (1996).- Fossil and living corallinaceans related to the Mediterranean endemic species Lithophyllum racemus (LAMARK) Foslie.- Facies, Erlangen, vol. 35, p. 275-292.

BASSO D. \& RODONDI G. (2006).- A Mediterranean population of Spongites fruticulosus (Rhodophyta, Corallinales), the type species of Spongites, and the taxonomic status of $S$. stalactica and S. racemosa.- Phycologia, Lawrence, vol. 45, p. 403-416.

Bahia R.G., Amado-Filho G.M., Maneveldt G.W., AdeY W.H., Johnson G., JesioneK M.B. \& LONGO L.L. (2015).- Sporolithon yoneshigueae sp. nov. (Sporolithales, Corallinophycidae, Rhodo- phyta), a new rhodolith-forming coralline alga from the southwest Atlantic.- Phytotaxa, Auckland, vol. 224, p. 140-158.

Bittner L., Payri C.E., Maneveldt G.W., Couloux A., Cruaud C., Reviers B. de \& Le Gall L. (2011).- Evolutionary history of the Corallinales (Corallinophycidae, Rhodophyta) inferred from nuclear, plastidial and mitochondrial genomes.- Molecular Phylogenetics and Evolution, Cambridge - MA, vol. 61, p. 697-713.

Braga J.C., Bosence D.W.J. \& SteneCK R.S. (1993).- New anatomical characteristics in fossil coralline algae and their taxonomic implications.- Palaeontology, London, vol. 36, p. 535-547.

Braga J.C., Bassi D., Zakrevskaya E. \& PetrovnaRADIONOVA E. (2005).- Reassessment of the type collection of MASLOV's species of Corallinales (Rhodophyta). I. Species originally attributed to Lithophyllum and Melobesia.- Revista Española de Micropaleontologia, Madrid, vol. 20, p. 207-224.

BRANDANO M. \& CORDA L. (2002).- Nutrients, sea level and tectonics: Constrains for the facies architecture of a Miocene carbonate ramp in central Italy.- Terra Nova, Hoboken, vol. 14, no. 4, p. 257-262.

Brandano M., Vannucci G., Pomar L. \& Obrador A. (2005).- Rhodolith assemblages from the lower Tortonian carbonate ramp of Menorca (Spain): Environmental and paleoclimatic implications.- Palæogeography, Palæoclimatology, Palæoecology, vol. 226, no. 3-4, p. 307323.

Brandano M., Vannucci G. \& Mateu-Vicens G. (2007).- Le alghe rosse calcaree come indicatori paleoambientali: L'esempio della rampa carbonatica Laziale-Abruzzese (Burdigaliano, Appennino centrale).- Bollettino della Società Geologica Italiana, Roma, vol. 126, no. 1, p. 55-69.

Brandano M., Cornacchia I., Raffi I., Tomassetti L. \& Agostini S. (2017).- The Monterey Event within the Central Mediterranean area: The shallow-water record.- Sedimentology, vol. 64 , p. 286-310.

BucuR I. \& FilipesCu S. (1994).- Middle Miocene red algae from the Transylvanian Basin (Romania).- Beiträge zur Paläontologie, Wien, vol. 19, p. 39-47.

Caragnano A., Foetisch A., Maneveldt G.W., Millet L., LIU L.-C., LIN S.-M., Rodondi G. \& PAYRI C.E. (2018).- Revision of Corallinaceae (Corallinales, Rhodophyta): Recognizing Dawsoniolithon gen. nov., Parvicellularium gen. nov. and Chambelainoideae subfam. nov. containing Chamberlainium gen. nov. and Pneophyllum.Journal of Phycology, Moss Landing, vol. 54, p. 391-409.

ChelaRU R. \& BUCUR I.I. (2016).- The taxonomy of Middle Miocene red algae from Gârbova de Sus Formation (Transylvanian Basin, Romania).- Carnets Geol., Madrid, vol. 16, no. 11, 
p. 307-336.

ChelaRu R., SĂSĂRAN E., TĂMAŞ T., BĂLC R., BUCUR I.I. \& PLEŞ G. (2019).- Middle Miocene carbonate facies with rhodoliths from the NW Transylvanian Basin (Vălenii Șomcutei Cave, Romania).- Facies, Erlangen, vol. 65, article no. 4, p. 1-16.

Cherchi A., Marini A., Murru M. \& Robba E. (1978).- Stratigrafia e paleoecologia del Miocene superiore della penisola del Sinis (Sardegna Occidentale).- Rivista Italiana di Paleontologia e Stratigrafia, Milano, vol. 84, p. 973-1036.

Coletti G., BAsso D. \& Corselli C. (2018).- Coralline algae as depth indicators in the Sommières Basin (early Miocene, Southern France).Géobios, Villeurbanne, vol. 51, no. 1, p. 1530.

Coletti G., Basso D., Frixa A. \& Corselli C. (2015).- Transported rhodoliths witness the lost carbonate factory: A case history from the Miocene Pietra da Cantoni limestone (NW Italy).- Rivista Italiana di Paleontologia e Stratigrafia, Milano, vol. 121, no. 3, p. 345-368.

Coletti G., Bosio G., Collareta A., BuCKeridge J., Consani S. \& El KATEB A. (2018).- Palaeoenvironmental analysis of the Miocene barnacle facies: Case studies from Europe and South America.- Geologica Carpathica, Bratislava, vol. 69, no. 6, p. 573-592.

Coletti G., El Kateb A., Basso D., Cavallo A. \& SPEZZAFERRI S. (2017).- Nutrient influence on fossil carbonate factories: Evidence from SEDEX extractions on Burdigalian limestones (Miocene, NW Italy and S France).- Palæogeography, Palæoclimatology, Palæoecology, vol. 475, p. 80-92.

Coletti G., Hrabovský J. \& Basso D. (2016).- Lithothamnion crispatum: Long-lasting species of non-geniculate coralline algae (Rhodophyta, Hapalidiales).- Carnets Geol., Madrid, vol. 16, no. 3, p. 27-41.

Conti S. (1943).- Contributo allo studio delle Corallinacee del Terziario Italiano.- Palaeontographia Italica, Pisa, vol. 41, p. 37-61.

Cornacchia I., Agostini S. \& Brandano M. (2018).Miocene oceanographic evolution based on the $\mathrm{Sr}$ and $\mathrm{Nd}$ isotope record of the Central Mediterranean.- Paleoceanography and Paleoclimatology, vol. 33, p. 31-47.

CRONQUist A. (1960).- The divisions and classes of plants.- The Botanical Review, vol. 26, p. 425482.

DolÁkovÁ N., BRzobohatÝ R., HLAdilová Š. \& NehyBa S. (2008).- The red-algal facies of the Lower Badenian limestones of the Carpathian Foredeep in Moravia (Czech Republic).- Geologica Carpathica, Bratislava, vol. 59, no. 2, p. 133-146.

Doláková N., Holcová K., Nehyba S., Hladilová Š., BRZOBOHATÝ R., ZÁGORŠEK K., HRABOVSKÝ J., SEKO M. \& UTESCHER T. (2014).- The Badenian parastratotype at Židlochovice from the perspecti- ve of the multiproxy study.- Neues Jahrbuch für Geologie und Paläontologie, Stuttgart, vol. 271 , p. 169-201.

De Jode A., David R., Haguenauer A., Cahill A.E., Erga Z., Guillemain D., Sartoretto S., Rocher C., Selva M., Le Gall L., Féral J.-P. \& Chenuil A. (2019).- From seascape ecology to population genomics and back. Spatial and ecological differentiation among cryptic species of the red algae Lithophyllum stictiforme/L. cabiochiae, main bioconstructors of coralligenous habitats.- Molecular Phylogenetics and Evolution, Cambridge - MA, vol. 137, p. 104-113.

Filipescu S. \& GîrbaceA R. (1997).- Lower Badenian sea-level drop on the western border of the Transylvanian Basin: Foraminiferal paleobathymetry and stratigraphy.- Geologica Carpathica, Bratislava, vol. 48, no. 5, p. 325-334.

Fravega P., Piazza M. \& Vannucci G. (1988).- Le corallinaceae della successione messiniana pre-evaporitica di Capo San Marco (Sardegna Occidentale). In: RobBA E. (ed.), Atti IV Simposio "Ecologia e Paleoecologia delle Comunità Bentoniche".- Museo Regionale di Scienze Naturali di Torino, Torino, p. 265-274.

FosLie M. (1900).- Den botaniske samling.- Kongelige Norske Videnskabers Selskabs Skrifter, Trondheim, vol. 9, p. 1-18.

HaRVey A.S., BroadWATER S.T., WoelKerling W.J. \& Mitrovski P.J. (2003).- Choreonema (Corallinales, Rhodophyta): 18S rDNA phylogeny and resurrection of the Hapalidiaceae for the subfamilies Choreonematoideae, Austrolithoideae, and Melobesioideae.- Journal of Phycology, Moss Landing, vol. 39, p. 988-998.

Hernandez-Kantun J.J., Gabrielson P., Hughey J.R., Pezzolesi L., Rindi F., Robinson N.M., PeÑa V., Riosmena-Rodriguez R., Le Gall L. \& Adey W. (2016).- Reassessment of branched Lithophyllum spp. (Corallinales, Rhodophyta) in the Caribbean Sea with global implications.- Phycologia, Lawrence, vol. 55, p. 619-639.

HeRnandez-Kantun J.J., Rindi F., AdeY W.H., Heesch S., Peña V., Le Gall L. \& Gabrielson P.W. (2015).- Sequencing type material resolves the identity and distribution of the generitype Lithophyllum incrustans, and related European species L. hibernicum and L. bathyporum (Corallinales, Rhodophyta).- Journal of Phycology, Moss Landing, vol. 51, p. 791-807.

HRABOVSKÝ J., BASSO D. \& DoláKOVÁ N. (2016).Diagnostic characters in fossil coralline algae (Corallinophycidae: Rhodophyta) from the Miocene of southern Moravia (Carpathian Foredeep, Czech Republic).- Journal of Systematic Paleontology, London, vol. 14, p. 499525.

Kato A., BABA M. \& SUdA S. (2011).- Revision of the Mastophoroideae (Corallinales, Rhodophyta) and polyphyly in nongeniculate species widely distributed on Pacific coral reefs.- Journal of Phycology, Moss Landing, vol. 37, p. 10911109. 
KüTZING F.T. (1841).- Uber die "Polypiers calcifères" des LAmouroux. In: Kützing F.T. (ed), Zu der öffentlichen Prüfung sämmtlicher Classen der Realschule zu Nordhausen, p. 3-34.

JOHANSEN H.W. (1981).- Coralline algae: A first synthesis.- CRC Press, Boca Raton -FL, 239 p.

LAMOUROUX J.V.F. (1812).- Extrait d'un mémoire sur la classification des polypiers coralligènes non entièrement pierreux.- Nouveau Bulletin des Sciences de la Société Philomatique, Paris, vol. 3, p. 181-188.

Le Gall L., Payri C.E., Bittner C.E. \& Saunders G.W. (2010).- Multigene polygenetic analyses support recognition of the Sporolithales, ord. nov.- Molecular Phylogenetics and Evolution, Cambridge - MA, vol. 54, p. 302-305.

Le Gall L. \& Saunders G.W. (2007).- A nuclear phylogeny of the Florideophycideae (Rhodophyta) inferred from combined EF2, small subunit and large subunit ribosomal DNA: Establishing the new red algal subclass Corallinophycidae.- Molecular Phylogenetics and Evolution, Cambridge - MA, vol. 43, p. 1118-1130.

Lemoine M. (1923).- Contribution à l'étude des Corallinacées fossiles. VII. Mélobésiées miocènes recueillies par $M$. BOUCART en Albanie.Bulletin de la Société Géologique de France (4e Série), Paris, vol. XXIII, no. 5-6, p. 275283.

LiU L.C., Lin S.M., Caragnano A. \& Payri C. (2018).- Species diversity and molecular phylogeny of non-geniculate coralline algae (Corallinophycidae, Rhodophyta) from Taoyuan algal reefs in northern Taiwan, including Crustaphytum gen. nov. and three new species.Journal of Applied Phycology, vol. 30, p. 34553469.

MASLOV V.P. (1962).- Fossil red algae of USSR and their connections with facies.- Trudy Geologicheskogo Instituta Akademii Nauk SSSR, Leningrad, vol. 53, p. 1-222.

Merwe E. van der, Miklasz K., Channing A., ManeVELDT G.W. \& GABRIELSON P.W. (2015).- DNA sequencing resolves species of Spongites in the Northeast Pacific and South Africa, including S. agulhensis sp. nov.- Phycologia, Lawrence, vol. 54, p. 471-490.

Nelson W.A., SutherLAND J.E., FARR T.J., HART D.R., NeILl K.F., KIM H.J. \& YoON H.S. (2015).Multi-gene phylogenetic analyses of New Zealand coralline algae Corallinapetra novaezelandiae gen. et sp. nov. and recognition of the Hapalidiales ord. nov.- Journal of Phycology, Moss Landing, vol. 51, p. 454-468.

Pardo C., Lopez L., Peña V., Hernandez-Kantun J., LE Gall L., Barbara I. \& BarReiro R. (2014).- A multilocus species delimitation reveals a striking number of species of coralline algae forming maerl in the OSPAR maritime area.PLoS ONE, San Francisco, vol. 9, no. 8, e104073, p. 1-12.

Pezzolesi L., Peña V., Le Gall L., Gabrielson P.W., Kaleb S., Hugley J.R., Rodondi G., Hernandez-
Kantun J.J., Falace A., Basso D., Cerrano C. \& RINDI F. (2019).- Mediterranean Lithophyllum stictiforme (Corallinales, Rhodophyta) is a genetically diverse species complex: Implications for species circumscription, biogeography and conservation of coralligenous habitats.- Journal of Phycology, Moss Landing, vol. 55, p. 473-492.

Pomar L., Obrador A. \& Westphal H. (2002).- Subwavebase cross-bedded grainstones on a distally steepened carbonate ramp, upper Miocene, Menorca, Spain.- Sedimentology, vol. 49 , p. $139-169$.

QuARANTA F., VANNUCCI G. \& BASSO D. (2007).Neogoniolithon contii comb. nov. based on the taxonomic re-assessment of MASTRORILLI's original material from the Oligocene of NW Italy (TPB).- Rivista Italiana di Paleontologia e Stratigrafia, Milano, vol. 113, p. 43-55.

ReYNAUD J.Y. \& JAMES N.P. (2012).- The Miocene Sommières basin, SE France: Bioclastic carbonates in a tide-dominated depositional system.- Sedimentary Geology, vol. 282, p. 360373.

Rindi F., Braga J., Martin S., Peña V., Le Gall L., Caragnano A. \& Aguirre J. (2019).- Coralline algae in a changing Mediterranean Sea: How can we predict their future, if we do not know their present?- Frontiers in Marine Science, Lausanne, vol. 6, 723, p. 1-29.

Rösler A., Perfectti F., Peña V. \& Braga J.C. (2016).- Phylogenetic relationships of Corallinaceae (Corallinales, Rhodophyta): Taxonomic implications for reef-building corallines.- Journal of Phycology, Moss Landing, vol. 52, p. 412-431.

Saint-Martin J.-P., Merle D., Cornée J.J., Filipescu S., SAint-Martin S. \& BucUR I.I. (2007).- Les constructions coralliennes du Badénien (Miocène moyen) de la bordure occidentale de la dépression Transylvanie (Roumanie).- Comptes Rendus Palevol, Paris, vol. 6, p. 37-46.

Silva P.C. \& JohANSEN H.W. (1986).- A reappraisal of the order Corallinales (Rhodophyceae).British Phycological Journal, London, vol. 21, p. 245-254.

Sissini M.N., Oliveira M.C., Gabrielson P.W., RoBINSON N.M., OKOLODKOV Y.B., RIOSMENA-RODRIGUEZ R. \& HORTA P. (2014).- Mesophyllum erubescens (Corallines, Rhodophyta) - so many species in one epithet.- Phytotaxa, Auckland, vol. 190, p. 299-319.

Vannucci G., Piazza M., Fravega P. \& Arnera V. (1993).- Le rodoliti del Miocene Inferiore del Settore SW del Bacino Terziario Piemontes (Spigno Monferrato - Alessandria).- Atti della Società Toscana di Scienze Naturali, Memorie (Serie A), Pisa, vol. 100, p. 93-117.

VANNUCCI G., Quaranta F. \& Basso D. (2008).- Revision and redocumentation of $M$. AIROLDI species of Lithophyllum from the Tertiary Piedmont Basin.- Rivista Italiana di Paleontologia e Stratigrafia, Milano, vol. 114, p. 515-528. 
Vannucci G., Quaranta F. \& Basso D. (2009).Historical type collections of fossil Corallinales and Sporolithales (Rhodophyta) in the DIP.TE. RIS.- Aracne Editrice, Roma, 65 p.
Woelkerling W.J., IRVine L.M. \& HaRVey A.S. (1993).- Growth-forms in non-geniculate coralline red algae (Corallinales, Rhodophyta).Australian Systematic Botany, Clayton South, vol. 6, p. 277-293. 
Table S1: Morphometric data of the studied specimens; the identification numbers of the specimens are the same used in the main text.

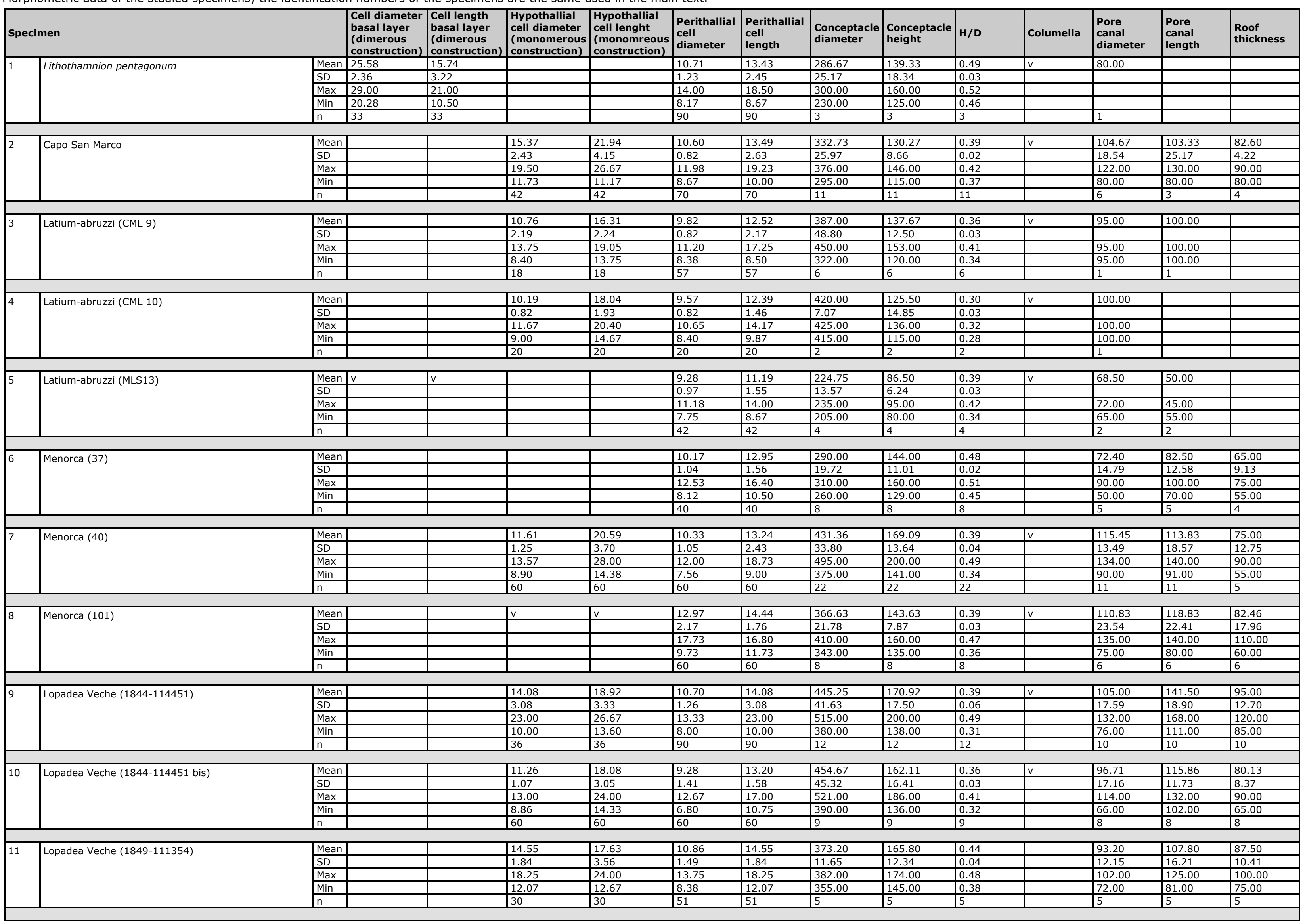




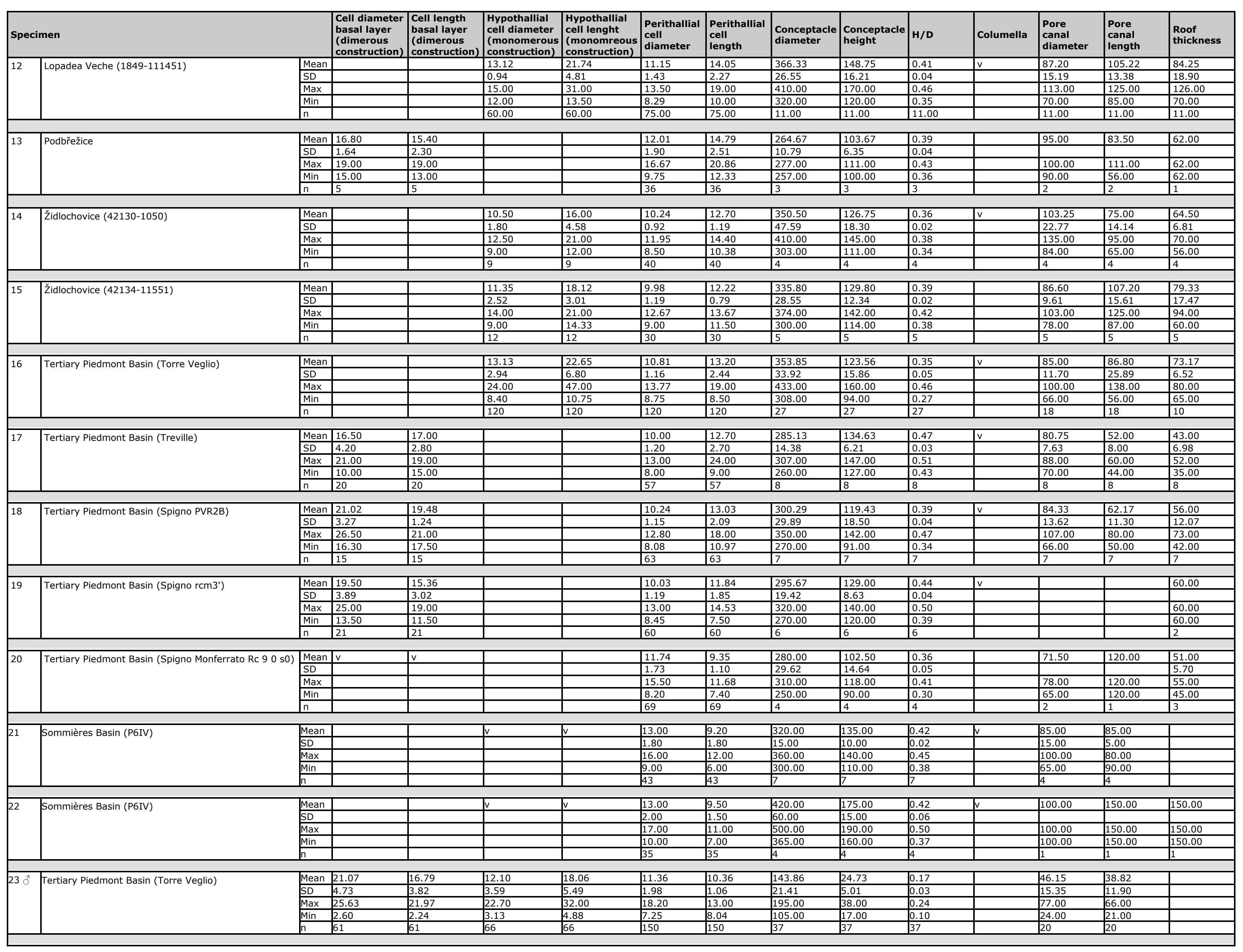




\begin{tabular}{|c|c|c|c|c|c|c|c|c|c|c|c|c|c|c|c|}
\hline \multicolumn{3}{|c|}{ Specimen } & \multirow{2}{*}{\begin{tabular}{|l|}
$\begin{array}{l}\text { Cell diameter } \\
\text { basal layer } \\
\text { (dimerous } \\
\text { construction) }\end{array}$ \\
16.20 \\
\end{tabular}} & \begin{tabular}{|l|} 
Cell length \\
basal layer \\
(dimerous \\
construction)
\end{tabular} & \begin{tabular}{|l|} 
Hypothallial \\
cell diameter \\
(monomerous \\
construction)
\end{tabular} & \begin{tabular}{|l|} 
Hypothalllial \\
cell lenght \\
(monomreous \\
construction)
\end{tabular} & \begin{tabular}{|l} 
Perithallial \\
cell \\
diameter
\end{tabular} & \begin{tabular}{|l} 
Perithallial \\
cell \\
length
\end{tabular} & $\begin{array}{l}\text { Conceptacle } \\
\text { diameter }\end{array}$ & $\mid \begin{array}{l}\text { Conceptacle } \\
\text { height }\end{array}$ & \multirow{2}{*}{\begin{tabular}{|l|}
$\mathrm{H} / \mathrm{D}$ \\
0.22
\end{tabular}} & \multirow[t]{2}{*}{ Columella } & \multirow{2}{*}{$\begin{array}{l}\begin{array}{l}\text { Pore } \\
\text { canal } \\
\text { diameter }\end{array} \\
36.75 \\
\end{array}$} & \multirow{2}{*}{ 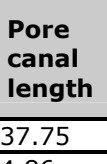 } & $\begin{array}{l}\text { Roof } \\
\text { thickness }\end{array}$ \\
\hline $24 \hat{\jmath}$ & Tertiary Piedmont Basin (Spigno Rc 90 ) & \begin{tabular}{|l|l|} 
Mean \\
\end{tabular} & & 13.33 & & & 11.32 & 8.82 & 111.33 & 24.22 & & & & & \\
\hline & & $\frac{S D}{\operatorname{Max}}$ & $\frac{1.54}{17.50}$ & $\frac{2.59}{15.17}$ & & & $\begin{array}{l}1.96 \\
16.83 \\
\end{array}$ & $\begin{array}{l}1.04 \\
10.77\end{array}$ & $\frac{10.91}{123.00}$ & 5.38 & 0.05 & & $\frac{11.79}{45.00}$ & $\begin{array}{l}4.86 \\
45.00\end{array}$ & \\
\hline & & Min & 14.50 & 11.50 & & & 8.67 & 6.30 & 94.00 & 17.00 & 0.14 & & 20.00 & 35.00 & \\
\hline & & & 10 & 10 & & & 58 & 58 & 9 & 9 & 9 & & & & \\
\hline \multirow[t]{4}{*}{25 o $^{1}$} & Tertiary Piedmont Basin (Spigno Rc 9 0) & \begin{tabular}{|l|l|} 
Mean \\
$口$
\end{tabular} & & $v$ & & & 11.94 & 10.13 & 130.00 & 22.00 & 0.17 & & & & \\
\hline & & \begin{tabular}{|l|l|l|l|} 
Max \\
Max
\end{tabular} & & & & & $\frac{1.14}{14.07}$ & $\frac{1.05}{12.08}$ & 1140.00 & 24.00 & 0.20 & & & & \\
\hline & & & & & & & 10.00 & 8.32 & 120.00 & 20.00 & 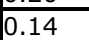 & & & & \\
\hline & & & & & & & 45 & 45 & & & & & & & \\
\hline
\end{tabular}

